Tania Espinoza*

\title{
The Truth of the Work of Art: Freud and Benjamin on Goethe'
}

\section{Benjamin on Goethe}

The truth that concerns Walter Benjamin in his essay "Goethe's Elective Affinities”, written in the early 1920s, is above all that of love. ${ }^{2}$ Goethe's novel Die Wahlverwandtschaften from 1809 tells the story of, as Benjamin put it, the "disintegration" of the marriage and the lives of Charlotte and Eduard, a couple of the German nobility. ${ }^{3}$ This disintegration is catalysed by the arrival to their estate of two additional characters, first the Captain, Eduard's friend from youth, and then Ottilie, Charlotte's foster niece; an arrival that, as in a chemical reaction, leads to the reconfiguration of their natural affinities.

After initially feeling a strong homosocial attachment to the Captain, Eduard becomes infatuated with Ottilie; while Charlotte, herself drawn to her niece, begins to desire the Captain. Under the spell of these new affinities, the host couple conceive a child, Otto, with the features of the guests. Ottilie assumes a maternal role with respect to the child, and later accidentally drops him from a boat. The baby drowns. ${ }^{4}$ Unable to bear the guilt, Ottilie starves herself to death and is soon followed to the tomb by Eduard, leaving Charlotte to deal with the aftermath of everyone's destructive tendencies.

1 An earlier version of this paper was presented at the $11^{\text {th }}$ meeting of the International Society for Psychoanalysis and Philosophy, SIPP-ISPP: The Truths of Psychoanalysis-held at Södertörn University, Stockholm, 2 May 2019. Initial reflections were shared at the workshop Benjamin: Aesthetics, Politics and the Philosophy of History, University of Gothenburg, 14 December 2018. I thank participants of both events for their comments.

2 Walter Benjamin, Howard Eiland, and Michael W. Jennings (eds.), Selected Writings: Volume 1, Belknap Press of Harvard Univ. Press, Cambridge, MA 2004, pp. 297-360.

3 Ibid., p. 308.

4 Marie Delcourt's analysis of the theme of exposure in Stérilités mystérieuses et naissances maléfiques dans l'Antiquité classique, Liège, 1938, could shed light on this element of the novel, namely, the sacrifice of a child who does not resemble its parents and is as such monstrous. 
In Benjamin's reading, however, it is not this turn of events that illustrates the vicissitudes of love. Love for him appears in its true form in a redoubling of fiction. That is, in a novella Goethe inserted about two-thirds into the novel: "The Curious Tale of the Childhood Sweethearts." ${ }^{5}$ This is a story, told by a visitor, of children of neighbouring families who grow up together as playmates and are expected by their parents to one day marry. Since they are much alike, however, their relationship is also one of violent rivalry. As they grow into adulthood the boy goes away to make a successful career in the military and the girl, who stays, is engaged to a sought-after suitor.

When the boy, on leave, returns home and meets the girl again, a natural affinity once more brings them close. Although mutual, the sentiment only represents a problem for the girl. With marriage as her only career prospect, she becomes obsessed by her re-found passion. The boy, on the other hand, has other ambitions to occupy him. Eager to return to them, he organises a yacht trip for the girl, her fiancé and the parents of the engaged couple as an engagement and farewell gift. Just as they are traversing a particularly difficult passage, the girl jumps into the current in order to kill herself and punish the boy for his indifference. The boy, who was commanding the ship after having taken over the tiller from a sleepy elderly captain, jumps after her, and finds her body lifeless. The ship they have abandoned seems to head for disaster.

Yet the narrative now transitions, almost seamlessly, into a utopia. ${ }^{6}$ The boy spots a house inhabited by a married couple, brings the girl's naked body to the shore, and manages to revive her. They unite in an embrace and are given the wedding attire of the local couple to clad themselves. When the party left on the ship arrives to the scene, unharmed, they find the youth dressed for marriage. The novella ends with the childhood sweethearts asking for the elders' blessings. In light of this vision, the affinities portrayed in the framing narrative appear, to Benjamin, to be mere semblances.

5 "Die wunderlichen Nachbarskinder". For the sake of consistency I will use the title that appears in the English translation of Benjamin's essay.

6 I thank Gisle Selnes for bringing my attention to the motif of shipwreck as doorway to utopia. See Selnes, Gisle, "Shipwreck and Utopia in Colonial Spanish America”, in Nowhere Somewhere: Writing, Space and the Construction of Utopia, ed. José Eduardo Reis and Jorge Bastos da Silva, Editora da Universidade do Porto, Porto 2006, pp. 55-67. 
Indeed, a sketch of Benjamin's argument can be traced by the oppositions he constructs between the novel and the novella. While the couples in the novel bring about their own ruin through the illusory freedom to make choices, the lovers in the novella are redeemed by a decision. While the couples in the novel are ruled by fate, the lovers in the novella transcend their fate through character. While the former can only achieve harmony by sacrificing their lives in atonement for their guilt, the latter, by risking their lives, achieve immortality. And so on.

In the contrast between the framing narrative and the story within the story, Benjamin finds the difference between immanence and transcendence that appears to redeem the writer. For Goethe - as possessed as he might have been in real life by the mythic forces of his reactionary strivings for security and worldly power, and as limited as he might have been by his erotic inhibitions, by his fear, indecisiveness, and superstition - still carries out in his work a struggle to disentangle himself from the same forces. It is this struggle that, according to Benjamin, makes a work of art genuine.

The downside is that true love becomes that which can only be realised in death. The action that precedes the union of the lovers in the novella is the girl's attempted suicide. That Benjamin himself understands the miraculous resurrection and marriage that follows as belonging to yet another layer of fiction - a messianic moment - is hinted at by his concluding words in the essay: "Those lovers never seize the body. What does it matter if they never gathered strength for battle? Only for the sake of the hopeless ones have we been given hope."7

Thus the oppositions Benjamin outlines do not represent a real conflict but merely an inverted reflection. ${ }^{8}$ Namely, the two faces of a fantasy of femininity as the death drive: one masochistic - Ottilie; the other sadistic - the girl. Are these women, like the lovers in the novella, not mirror images of each other? The recursive structure at the core of Benjamin's redemptive reading does not

7 Walter Benjamin, “Goethe's Elective Affinities”, in Selected Writings: Volume 1, Walter Benjamin, ed. Howard Eiland and Michael W. Jennings, Belknap Press of Harvard University Press, Cambridge, Massachusetts 2004, p. 356.

8 Here I have in mind the distinction Kant draws in the Critique of Pure Reason between a dialectic or real conflict and an analytic contradiction. See Monique David-Ménard, "Kant et le négatif”, in Deleuze et la psychanalyse: L'altercation, PUF, Paris 2005, pp. 153-173. 
resolve this specular trap but replicates it, which may account for the suffocating tone of the essay.

A healthier approach to fiction is exemplified in the novel by the character of Charlotte, who, after listening to the story of the "Childhood Sweethearts," recognises in it embellished elements of a true story involving the Captain and a neighbour of his whose destiny we ignore. She, as a mature woman, has witnessed enough shipwrecks to know that hope is better invested in contingency than in utopia. Yet Benjamin at this point seems too occupied in chastising her to be able to notice. ${ }^{9}$

\section{Freud on Goethe}

In “A Childhood Recollection from Dichtung Und Wahrheit” (1917), Freud ventures an analysis of Goethe from an anecdote that appears in the first few pages of the writer's autobiography. ${ }^{10}$ It is Goethe's earliest memory. Little Johann Wolfgang is playing kitchen with miniature crockery pots and pans that had been bought for him and his younger sister as toys. Then, "since this seemed to lead to nothing," he gets the idea of throwing one out onto the street and is "overjoyed to see it go to bits so merrily." Encouraged by a group of neighbours, he throws another and then another, and then goes to the kitchen table and begins to throw all the real crockery that had just been acquired at the fair along with the toys. No adult stops him until it is too late.

The story is told from the point of view of the mature man, who recollects having often been teased by these neighbours, "three orphan sons of the magistrate,"

9 Benjamin's picture of the "angel of history," who wants to "make whole what has been smashed," can be read as his later rewriting of the scene in which Charlotte reflects on being shipwrecked on dry land, in the beginning of Chapter Ten of Elective Affinities chapter that contains the novella - now from the point of view of little Johann Wolfgang as portrayed by Freud. I turn to this portrait in the next section of the essay. See "On the Concept of History”, Benjamin, Walter, Howard Eiland, and Michael W. Jennings (eds.), Selected Writings: Volume 4, Belknap Press of Harvard Univ. Press, Cambridge, MA 2006. pp. 389-400. (p. 392.)

10 Sigmund Freud, "A Childhood Recollection from Dichtung Und Wahrheit”, in Sigmund Freud, James Strachey and Anna Freud, The Standard Edition of the Complete Psychological Works of Sigmund Freud: Volume XVII (1917-1919), Hogarth Press, London 1973, pp. 145-156. 
to carry out these sorts of pranks. ${ }^{11}$ Goethe's narrator speaks insistently of how fond these neighbours/orphan brothers were of little Johann Wolfgang, how interested they were in him, how much they loved and encouraged him, which makes this episode resonate with that myth Freud had placed as the origin of society in Totem and Taboo four years earlier: the primal horde of brothers. In fact, this childhood memory can be read as a primal scene of initiation into society conceived as a brotherhood through a violent act that is at the same time an attack on the private, feminine world of the home, the domus.

Although the narrator tries to hide the lasting consequences of this unbridled destructiveness beneath the manic enjoyment of its spectators, Freud is attentive to its serious effects. This "mischievous trick with damaging effects on the household economy, carried out under the spur of outside encouragement, is certainly no fitting headpiece for all that Goethe has to tell us of his richly filled life," says Freud before he goes on to claim that in some way it is. ${ }^{12}$

What Freud does in the rest of the essay is to compare Goethe's tantrum first with an identical one recounted by one of his male patients, then with a similar one recalled by another male patient, and finally with two similar cases, a male and a female, reported by a female colleague of his. Both of Freud's patients were impaired in their capacity to love and the second also suffered from "embitterment against women." These cases, Freud concludes, "establish without further analytic effort that the bitterness children feel about the expected or actual appearance of a rival finds expression in throwing objects out of the window and other acts of naughtiness and destructiveness." ${ }^{13}$

In Freud's interpretation, Goethe's cathartic scene is part of a drama of sibling rivalry. Through biographical information, Freud concludes that the memory could have coincided with the birth of one of Goethe's siblings, Hermann Jakob, who, like four other ones, would die in infancy, him at the age of six. Little Johann Wolfgang would like to throw his brother out of the window to keep his mother's attention all to himself, but he cannot, so instead he smashes his

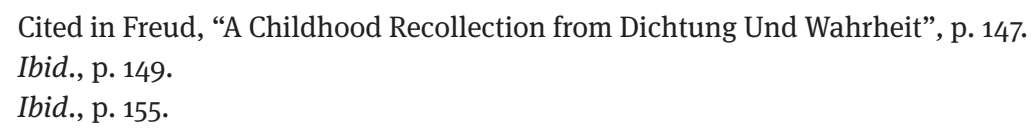


toys as "a 'magic action' by which the child (Goethe as well as [Freud's] patient) [gives] violent expression to his wish to get rid of a disturbing intruder." ${ }^{14}$

Freud denies that the episode of jealousy might have something to do with Goethe's sister Cornelia, fifteen months Goethe's junior, who was his playmate and would live until the age of 27. "This slight difference in age," says Freud, "almost excludes the possibility of her having been an object of jealousy. It is known that, when their passions awake, children never develop such violent reactions against the brothers and sisters they find already in existence, but direct their hostility against the newcomers. Nor is the scene we are endeavouring to interpret reconcilable with Goethe's tender age at the time of, or shortly after, Cornelia's birth." ${ }^{15}$

After thus discounting Cornelia, however, there are two siblings whose births Freud considers as perhaps having coincided with Goethe's childhood recollection: Hermann Jakob, born when Goethe was three and a quarter years old, and Katharina Elisabetha, born when Goethe was about five years old. As if to underline the arbitrary nature of the choice, Freud comments: "Both ages come under consideration in dating the episode of the throwing out of the crockery. The earlier is perhaps to be preferred; and it would best agree with the case of my patient, who was about three and a quarter years old at the birth of his brother." ${ }^{16}$

It is true that a baby of fifteen months is not likely to play in this manner, yet this same argument should apply for Johann Wolfgang's usual playmate Cornelia. If Goethe, as Freud suggests, was three and a quarter years old when this episode occurred, his sister would have been around two years old. While not impossible, it is more likely that miniature pots and pans would have been bought for children who were slightly older. If one considers Goethe not alone but usually playing with his younger sister, it makes more sense to place the scene when Goethe was around five and his sister Katharina Elisabetha was born.

Charles Kligerman suggested that Freud's exempting of Cornelia as a possible object of jealousy might act as a screen for the memory of Freud's own lost next

\footnotetext{
Ibid., p. 152.

Ibid., p. 151, my emphasis.
}

16 Ibid. 
younger brother Julius, born eighteen months after him. ${ }^{17}$ We might, however, also recall Freud's interpretation of his Dream of the Botanical Monograph that links his love of books and artichokes to the game of destroying a book of colour plates he played with his eldest sister Anna: "I was then five years old, and my sister not yet three, and the picture of us children blissfully pulling this book to pieces (like an artichoke, leaf by leaf, I must add) is almost the only clear memory of this period of my life I still retain." ${ }^{18}$

Now, considering the similarity between the scenes of children playing at destroying, it could also be the case that Goethe's earlier age is preferred by Freud only so as to conceal the agreement with his own age in this memory of playing with Anna. ${ }^{19}$ Conversely, Goethe's childhood recollection, with its sibling axis represented by the "orphan brothers," could, on the other hand, be read through Freud's memory of sharing with his sister Anna the pleasures of destruction, as Goethe's screen memory of a similar situation involving his own sister. For we may ask: Where was little Cornelia while Johann Wolfgang smashed the crockery pots and pans that were bought for both to play with? Should one not conclude from her absence that the destruction of their toys was also an act of hostility against her? Or could she have been present? Could a "construction in analysis," to use the concept Freud turned towards at the end of his life, restore the sister to the primal scene of destruction? ${ }^{20}$

Both Freud's and Goethe's scenes are part of a larger narrative of how an oeuvre is born as a reparatory response to a catastrophe in early childhood. As Goethe says, "the damage was done, and to make up for so much broken earthenware

${ }_{17}$ Charles Kligerman, “Goethe: Sibling Rivalry and Faust”, Psychoanalytic Inquiry (4/1984), p. 558.

18 Sigmund Freud, The Interpretation of Dreams, trans. Ritchie Robertson and Joyce Crick, Oxford University Press, New York 1999, p. 131.

19 That this is an allusion to masturbation is made clear by Freud. See Alexander Grinstein, "Freud's Dream of the Botanical Monograph", Journal of the American Psychoanalytic Association, 9 (1961), pp. 480-503, (pp. 500-501). For a different yet compelling interpretation of this memory, cf. Diane O'Donoghue, “'Lingua Flora': Deciphering the 'Dream of the Botanical Monograph”, American Imago, 62 (2, 2005), pp. 157-177.

${ }_{20}$ See "Constructions in Analysis" in: Freud, Sigmund, Anna Freud, James Strachey, Alix Strachey, and Alan Tyson, The Standard Edition of the Complete Psychological Works of Sigmund Freud: Volume XXIII (1937-1939), Hogarth Press and the Institute of Psychoanalysis, London 1964, pp. 255-269.» 
there was at least an amusing story." ${ }^{21}$ Goethe introduces this memory through the light note of the brothers who teased him about this until they died, yet omits to describe the reaction of the women, who were presumably the ones most concerned with the crockery that was to last for a time.

Freud associates his bibliophilic passion and his habit of reading whole monographs as a student to this episode, both as a rebellion against his father's instruction to tear the book apart, and as a continuation of its sadistic component in the act of devouring books, tearing arguments apart. Yet the question of the female playmate and companion in this activity, present/absent from this primal scene of intellectual passion, needs to be put into a context of gender inequality in which sisters sacrificed their education for that of their brothers. ${ }^{22}$

\section{Siblings}

Juliet Mitchell speaks of how her work with male hysteria led her to pay more attention to siblings. That is, to look for the dramas of love, hate, incest, and murder that characterise human experience laterally along the axis of peers/ neighbours/equals, rather than vertically along the hierarchical and generational axis of parents and teachers.

In Siblings: Sex and Violence, she argues that the experience of having or imagining that one could have a sibling, so far shared universally, is one that poses a fundamental threat to our existence. ${ }^{23}$ Not only, as Freud argues in his note

21 Cited in Freud, “A Childhood Recollection from Dichtung Und Wahrheit”, p. 148.

22 In this light, one could add a layer to the interpretation of the childhood memory of stealing a little girl's bunch of dandelions in Freud's 1899 paper “Screen Memories" published the year after Freud had the Dream of the Botanical Monograph. Here, the sexual meaning given by Freud, i.e. a desire to deflower, can be read as a screen for the envy of a female peer's intellectual talent. We recall that the little girl, in tears after being despoiled by the two boys, is given bread by a peasant woman in compensation. This is coherent with the rest of the interpretation, where Freud speaks of the passion for study that absorbs him at the time of seeing this girl, his cousin, again at the age of twenty when he is at University. Then, the analyst's voice in the dialogue suggests that the flowers symbolise the student's impractical ideals, and the bread a bread and butter occupation. The meaning of this memory might be the wish that the women of his generation, whose opportunity to develop their intellectual talents were snatched away by their male peers, get something delicious in compensation, such as the pleasures of maternity.

23 Juliet Mitchell, Siblings: Sex and Violence, Polity Press, Cambridge 2003. 
on Goethe, is it a question of losing the exclusivity of the mother's gaze, but it is about this loss translating, for the child, into an outright risk of annihilation. Our degree of hysteria, in her theory, results from the way we negotiate this trauma. The opposite poles in the health spectrum are the (healthy) ability to understand seriality - i.e. that there is space for others who are similar yet different and the (pathological) experience of life as being about killing or being killed. "Hysterics," says Mitchell, "protest that someone standing in the same place as themselves [in the same generation, social group, etc.] eradicates them unless they can eradicate this other first." ${ }^{24}$

If a sibling is an intruder, however, she or he also offers the possibility of a narcissistic extension of the self. "Her Majesty the Baby" expects the sibling to be "more of herself," says Mitchell. Thus, in the sibling drama, "the ecstasy of loving one who is like oneself is experienced at the same time as the trauma of being annihilated by one who stands in one's place." ${ }^{25}$ Like the hysteric, Mitchell says, "the sibling loves what he hates."

This allows us to specify the vision of true love that Benjamin identifies in the novella. The love therein is certainly sibling-like and the lovers charming hysterics, even if this similar pathology has dissimilar consequences for the boy and the girl: it makes him rapidly attain worldly success, while it makes her unsuitable for marriage. The couple are also, as we said, ferocious rivals. Benjamin hardly mentions the violence that is in question in the history of these neighbours where the girl once almost tears the boy's eyes out. The narrator is clear in that the girl is the only competitor that nature assigned the boy and that this partly explains the boy's complacency at her engagement to someone else, as a welcome opportunity to rid himself of a rival. At the same time, the girl's, to use Benjamin's term, "courageous decision" to cast herself into the dangerous current for the sake of true love, is described by Goethe in a less charitable fashion: ${ }^{26}$

She determined that she would die to punish the once hated, and now so passionately loved, youth for his want of interest in her; and as she could not possess

24 Ibid., p. 104.

25 Ibid., p. 10.

26 Benjamin, “Goethe's Elective Affinities”, p. 332. Benjamin only uses the term decision to describe the action of the lovers, in plural: "both dive down into the living current [...]," thus erasing the important chronology of events and the asymmetry of their actions. 
himself, at least she would wed herself for ever to his imagination, and to his repentance. Her dead image should cling to him, and he should never forgive himself for not having understood, not examined, not valued her feelings toward him. "This singular insanity accompanied her wherever she went." 27

Are we to conclude from this that all true love is sibling-like, or is it rather that that which Benjamin identifies as true love is Goethe's hysterical fantasy? That a sibling trauma structured Goethe's love life seems suggested by the poem "Warum gabst du uns die tiefen Blicke” (1776), dedicated to Charlotte von Stein: “Tell me, how we're bound in such a knot? / From an old existence we were sharing? / You're the wife, the sister I forgot?" ${ }^{28}$ Both Benjamin and Freud cite the line "Ach, du warst in abgelebten Zeiten / Meine Schwester oder meine Frau."29

"We do not see," says Mitchell, "when a man identifies with his sister along narcissistic lines. Yet he can still hate her and wish her dead and love her and want her incestuously - this is surely a familiar scenario in many a problematic marriage?"30 For all her identification of the diagnostic blindness, however, Mitchell seems to believe that the solution lies in reconfiguring love along vertical, Oedipal lines, rather than horizontal ones. Does the problem, however, not also lie in this not seeing, that is, in the difficulty, for both men and women, of recognizing, accepting and sublimating their love and hate for women, not only as mothers/daughters, but also as sisters and peers?

Goethe's recollection of smashing crockery might thus have more to do with sisters than Freud was willing to admit and as such might be related to the story of the lovers in the novella. ${ }^{31}$ The author casts the sister from the boat yet is able to bring her lifeless body to a redeemed life in a marriage in heaven. In the novel, Nanny, another sibling-survivor, throws herself from a window, breaking all

${ }^{27}$ Johann W. Goethe and Nicholas Boyle, Selected Works: Including the Sorrows of Young Werther, Elective Affinities, Italian Journey, Faust, A.A. Knopf, New York 2000, p. 304.

${ }_{28}$ Goethe, Johann W. Goethe: Selected Poems. Suhrkamp/Insel Publishers Boston, Cambridge, MA 1983, p. 61.

${ }_{29}$ See "On Some Motifs in Baudelaire”, in Selected Writings, Volume 4, On Some Motifs in Baudelaire", in Selected Writings, Volume 4, p. 338. See Freud, “The Goethe Prize”, in Sigmund Freud and Neil Hertz, Writings on Art and Literature, Stanford University Press, Stanford 1997, p. 258.

30 Mitchell, Siblings, p. 149.

${ }^{31}$ As well as to Freud's earliest passion, and favourite flower, i.e. the artichoke bloom. 
her bones, and is miraculously reconstituted by contact with the corpse of her adoptive mother, Ottilie, with whom she posthumously reconciles. The novella offers a lateral reconciliation, the novel a vertical one. Benjamin saw the ideal of romantic love in the novella. Yet both are predicated on the sacrifice of a sibling. For however true love in the novella might have rung for Benjamin, in it, as in the frame, there is still only room for one.

Can there be another script for love among equals? Mitchell seems to offer the outline of a theory of lateral castration, which she sometimes calls, playing with Lacan, the "law of the mother."

The sibling experience organizes narcissism into self-esteem through accepted loss - through a mourning process of the grandiose self, the 'death' of His Majesty the Baby. This is the necessary acceptance that one is ordinary, which does not mean that one is not unique [...]. Without this gradual and never fully established transformation of the self, the distress and disruption of the anti-social child or the maladies of madness are on the cards..$^{2}$

Goethe's writing, like Freud and Benjamin's readings of it, in different ways, still advance this infinite transformation. In the case of Benjamin, his essay on the Elective Affinities as well as a later biographical sketch explicitly attack the "man of genius" approach to Goethe of the Stefan George circle. By comparing the child Goethe to other patients, first his own and then those of a colleague, Freud seems to pronounce, with foresight, Juliet Mitchell's "law of the mother" on little Johann Wolfgang. That is, to assign each child a place within the group that is not mutually exclusive with the others, to say there can be "space for one who is the same and different." ${ }^{33}$

This not only becomes the key to an insightful reading, but makes Freud partake in the same "sibling experience" by corroborating his findings with those of a peer, and importantly, a woman. Such gesture is perhaps echoed in Freud's choice in his speech accepting the Goethe prize in 1930 to adapt the theme proposed to him of "his inner relations as a man and scientist to Goethe" to one that, as he put it in his letter to Dr Alfons Paquet, would defend his peers, the

32 Mitchel, Siblings, p. 205.

33 Ibid., p. 52. 
analysts, "against the reproach of having offended against the respect due to the great man by the analytic attempts they have made on him." ${ }^{34}$ Freud staged his defence, however, by recalling that the truth of the work of art, like the truth of the artist, is a secret.

\section{References}

Benjamin, Walter, “Goethe's Elective Affinities”, in Selected Writings: Volume 1, Walter Benjamin, Howard Eiland, and Michael W. Jennings (eds.), Belknap Press of Harvard University Press, Cambridge, MA 2004, pp. 297-360

- "On Some Motifs in Baudelaire” in Selected Writings: Volume 4, Walter Benjamin, Howard Eiland and Michael W. Jennings (eds.), Belknap Press of Harvard University Press, Cambridge, MA 2006

David-Ménard, Monique, “Kant et le négatif”, in Deleuze et la psychanalyse: L'altercation, PUF, Paris 2005, pp. 153-173

Delcourt, Marie, Stérilités mystérieuses et naissances maléfiques dans l'Antiquité classique, Presses Universitaires de Liège, Liège 1938

Freud, Sigmund, "Screen Memories", in Sigmund Freud, James Strachey, and Anna Freud, The Standard Edition of the Complete Psychological Works of Sigmund Freud: Volume Iii (1893-1899), Hogarth Press, London 1973, pp. 299-322

- The Interpretation of Dreams, trans. Ritchie Robertson and Joyce Crick, Oxford University Press, New York 1999

- "A Childhood Recollection from Dichtung Und Wahrheit", in Sigmund Freud, James Strachey, and Anna Freud, The Standard Edition of the Complete Psychological Works of Sigmund Freud: Volume Xvii (1917-1919), Hogarth Press, London 1973, pp.145-156

- "The Goethe Prize”, in Freud, Sigmund, and Neil Hertz, Writings on Art and Literature, Stanford University Press, Stanford 1997

- "Constructions in Analysis", in Freud, Sigmund, Anna Freud, James Strachey, Alix Strachey, and Alan Tyson, The Standard Edition of the Complete Psychological Works of Sigmund Freud: Volume XXIII (1937-1939), Hogarth Press and the Institute of Psychoanalysis, London 1964, pp. 255-269

Goethe, Johann, W., Goethe: Selected Poems, Suhrkamp/Insel Publishers Boston, Cambridge, MA 1983

Goethe, Johann, W., and Nicholas Boyle, Selected Works: Including the Sorrows of Young Werther, Elective Affinities, Italian Journey, Faust. A.A. Knopf, New York 2000

Grinstein, Alexander, "Freud's Dream of the Botanical Monograph”, Journal of the American Psychoanalytic Association 9 (1961)

34 See Freud, “The Goethe Prize”, p. 257. 
Kligerman, Charles, “Goethe: Sibling Rivalry and Faust”, Psychoanalytic Inquiry 4 (1984), No. 4

Mitchell, Juliet, Siblings: Sex and Violence, Polity Press, Cambridge 2003

O’Donoghue, Diane, “'Lingua Flora': Deciphering the 'Dream of the Botanical Monograph”, American Imago 62 (2005), No. 2

Selnes, Gisle, "Shipwreck and Utopia in Colonial Spanish America”, in José Eduardo Reis and Jorge Bastos da Silva (eds.) Nowhere Somewhere: Writing, Space and the Construction of Utopia, Editora da Universidade do Porto, Porto 2006, pp. 55-67 